aangeboden, met verzoek daarvoor een billijken prijs te bepalen.

$\mathrm{Na}$ uitvoerige gedachtenwisseling over den inhoud en de waarde van het aangeboden handschrift wordt de Secretaris gemachtigd daaromtrent met den heer $M$. Nijhoff in nader overleg te treden.

Door den Penningmeester worden eenige financiëele mededeelingen gedaan, waaruit blijkt dat ter zijner beschikking is een som van ongeveer tweeduizend gulden, welke hij gaarne rentegevend zou maken, weswege hij machtiging vraagt ze te mogen deponeeren bij de firma Lissa en Kann, hier ter stede.

Zonder beraadslaging wordt de gevraagde machtiging verleend.

Naar aanleiding eener vraag van den heer Meinsma deelt de Secretaris mede, dat de uitgave van de eerste aflevering der Bijdragen voor dit jaar door onvoorziene omstandigheden is vertrangd geworden, doch in het laatst van Mei of 't begin van Juni kan worden verwacht.

Niets meer hierna aan de orde zijnde, wordt de Vergadering door den Voorzitter gesloten.

\title{
222STE BESTUURSVERGADERING,
}

\author{
GEHOUDEN 18 JUNI 1881.
}

Tegenwoordig de heeren van Rappard (Voorzitter), Kniphorst (Penningmeester), Robidé van der Aa, Quarles van Ufford, Lammers van Toorenburg, van der Gon Netscher, Niemaun, Juynboll en Wijnmalen (Secretaris). Afwezig de heeren van Goltstein, Mees, Meinsma en Humme.

De notulen van het verhandelde in de vorige Vergadering worden gelezen en goedgekeurd. 
De Voorzitter deelt mede, dat, aangezien er geen stukken van eenig belang of van spoedeischenden aard te behandelen waren, de vergadering, die in de maand Mei had moeten gehouden zijn, niet is uitgeschreven, waarvan de leden van het Bestuur tijdig door den Secretaris in wetenschap zijn gesteld.

De Secretaris doet vervolgens opgave van de aangekochte en ten geschenke ontvangen boekwerken, in verband waarmeê door hem mededeeling wordt gedaan van den ontvangst van missives :

10. van den Minister van Marine, dd. 23 April 1881, Letter A, $\mathrm{n}^{0}$. 67 ;

$2^{0}$. van den Minister van Binnenlandsche Zaken, dd. 15 Juni 1881, no. 1277, Afd. K. en W.;

30. van het Koninklijk Zoölogisch Genootschap Natura Artis Magistra, te Amsterdam, van 12 Februari 1881;

$4^{0}$. van het Bestuur van het Nederlandsch Zendelinggenootschap te Rotterdam, van 23 April 1881; en

$5^{0}$. van den heer Nicolas Soraluce, te San Sebastian,

allen ten geleide van boekwerken ten behoeve der Bibliotheek van het Instituut.

Bereids is voor deze geschenken door den Bibliothecaris de dank van het Instituut angeboden.

\section{Nog zijn ingekomen :}

10. eene missive van den Minister van Buitenlandsche Zaken, van 5 Mei ll., $\mathrm{n}^{n}$. 3563, 2e afd, houdende dankbetuiging voor de toezending van een exemplaar van het Verslag over den staat der Bibliotheek van het Instituut over 1880, onder mededeeling tevens dat $\mathrm{Zr}$. Ms. vertegenwoordigers te Londen, Parijs, Madrid en Lissabon zijn verzocht de overige aan den Minister gezonden exemplaren aan de Engelsche, Fransche, Spaansche en Portugeesche regeeringen aan te bieden, als blijk van erkentelijkheid voor de toegezonden werken, onder aanbeveling van de belangen der Bibliotheek van het Instituut.

20. eene missive van de Regia Lynceorum Academia te Rome, van den 20 Mei ll., houdende dankbetuiging voor de toegezonden afleveringen van de Bijdragen. 
30. eene missive, met bijlagen, van het Bestuur van het "Technological, Industrial and Sanitary Museum of New South Wales," te Sydney, houdende mededeeling van de oprichting van het genoemde Museum en verzoek om het te plaatsen op de lijst der wetenschappelijke instellingen, waarmeê het Instituut in betrekking staat.

De missives sub $10-3^{0}$ worden voor kennisgeving aangenomen.

40. eene missive van het lid A. H. L. Badings, te Amsterdam, van 16 April 11., waarin de aandacht wordt gevestigd op de omstandigheid dat tot heden geene pogingen in het werk zijn gesteld om aan onderofficieren en korporaals van het Ned. Ind. leger, die dikwerf een jaar te Harderwijk bij het koloniaal Werfdepôt verblijven, eenig onderricht in de Maleische taal te geven, opdat zij in Indië aankomende en gedurende hun verder verblijf aldaar de vruchten kunnen plukken.

Naar aanleiding dezer missive wordt de vraag overwogen of het wenschelijk is op het door den heer Badings medegedeelde feit ook de aandacht van den Minister van Koloniën te vestigen, ten einde zooveel doenlijk in de bestaande leemte te voorzien. Daar het der Vergadering met 't oog op 't kort verblijf der militairen te Harderwijk twijfelachtig voorkomt of het geven van eenig onderricht in de Maleische taal wel aan het beoogde doel zou beantwoorden, terwijl het bovendien onzeker is of niet reeds elders of op andere wijze in de leemte wordt voorzien, wordt besloten voorshands geene voorstellen in den geest des heeren Badings aan de Regeering in overweging te geven, en zijn schrijven voor kennisgeving aan te nemen.

$5^{0}$. eene tweede missive van het lid Badings, van 15 Mei jl., houdende verzoek om toezending van een exemplaar van de catalogi van de bibliotheken van het Indisch Genootschap en van het Instituut.

De Secretaris wordt gemachtigd aan het verzoek te voldoen, voor zoover het deu catalogus der bibliotheek van het Indisch Genootschap betreft, onder mededeeling wijders, dat die van de boekerij van het Instituut voor de pers wordt gereed gemaakt. 
$6^{0}$. eene missive van de firma Wed. E. Spanier en Zoon, lithographen, te 's Gravenhage, houdende eene aanbeveling voor de levering van eenig drukwerk.

Voor kenisgeving aangenomen.

70. eene missive van het Bestuur van het Algemeen Nederlandsch Vredebond, houdende verzoek, om, evenals twee jaren geleden, het vergaderlokaal van het Instituut te willen afstaan voor de Algemeene Vergadering van het Vredebond, op 6 Juli a. s. te houden.

$\mathrm{Na}$ eenige gedachtenwisseling wordt besloten voor ditmaal nog het gevraagde verlof te verleenen, terwijl voorts wordt besloten voortaan aan geene vereeniging, van welken aard ook, het gebruik der lokalen af te staan met 't oog op de moeielijkheden, die daardoor voor het Instituut zouden kunnen ontstaan.

80. missives van de hh. Dr. W. Pleyte, te Leiden, J. A. Kruyt, te Djeddah en N. de Miklouho-Maclay, te Sydney, allen houdende bericht van de aanvaarding van het lidmaatschap.

Voor kennisgeving aangenomen.

Ter tafel wordt gebracht eene missive van Commissarissen van het Instituut van 22 April 1881, Lett. B/66, ten geleide

10. van een cognossement voor éen kist en twee rollen boeken en kaarten bevattend, aan 't adres van het Instituut verzonden per stoomschip Celebes, onder mededeeling voorts van hetgeen tot dusver ten behoeve der bibliotheek reeds werd verricht of alsnog zal worden gedaan.

20. van een staat der in Ned. Indië op 1 Januari 1881 aanwezige leden, van hen, die in den loop van het afgeloopen jaar van de ledenlijst zijn afgevoerd, gelijk mede van hen die in dat jaar naar Europa vertrokken of overleden zijn, met kennisgeving wijders dat de hh. Habbema, van der Toorn, Albrecht en Audrée Wiltens, als hebbende het lidmaatschap aanvaard, als nieuwe leden zijn aangeteekend.

30. van de verantwoording van het financieel beheer over 1880, met een staat der achterstallige contributiën van leden, die zich in Indië bevinden, een staat van het boekenfonds onder ultimo 1583 , benevens een wissel groot $f 800 \mathrm{~N}$. Ct, 
zijnde het saldo van de rekening over het afgeloopen jaar en der sedert ontvangen subsidiën en contributiën.

Met belangstelling wordt van een en ander kennis genomen en de Secretaris gemachtigd:

a. Commissarissen den dank van het Bestuur over te brengen voor hunne voortdurende belangelooze, doch ijverige behartiging der belangen van het Instituut in het algemeen en van zijne bibliotheek in 't bijzonder, en wat deze verzameling aangaat, verder met Commissarissen in zoodanig overleg te treden als in haar belang wenschelijk mag worden geacht;

b. de ontvangst te erkennen van de bij de missive ge. voegde bijlagen, gelijk mede van de verantwoording van hun financieel beheer en van den wissel groot $f 800 \mathrm{Ned}$. Ct, onder mededeeling dat een en ander in goede orde is bevonden en mitsdien goedgekeurd met dankzegging voor de zorg, daaraan besteed.

$c$. eindelijk Commissarissen mede te deelen, dat tot leden van het Instituut zijn benoemd de hh. J. Kreemer en H. L. Neumann, die daartoe aanzoek hebben gedaan.

Door den Secretaris wordt medegedeeld dat het hem niet gelukt is het handschrift over Atjeh van wijlen den heer Leupe van diens Erven over te nemen, waarom hij verzoekt, met 't oog op de aanstaande auctie der bibliotheek van wijlen genoemd medelid, alsnog diligent verklaard te worden.

De Secretaris brengt ter tafel een exemplaar van de eerste aflevering, met atlas, van het reisverhaal van den heer Carl Bock, waarvan de verzending aan al de leden van het Instituut eerlang kan worden tegemoetgezien.

$\mathrm{Na}$ eenige mededeelingen omtrent den druk van de 2e aflevering der Bijdragen, waarin, onder meer, het vervolg van de bekende studiën van het lid Tiele zal worden opgenomen, wordt vervolgens de ontvangst medegedeeld, door tusschenkomst van Prof. K. Martin te Leiden, van een nog ongedrukt gedeelte van de bekende reizen in Sumatra van den heer Horner. Na gedachtenwisseling wordt besloten den Secretaris op te dragen, in overleg met den hoogleeraar Martin, het toegezonden hs. voor den druk te bewerken. 
De Secretaris herinnert der Vergadering aan het 40jarig jubilé van den hoogleeraar P. J. Veth, op den 22 Juni a.s. en geeft in overweging den Jubilaris alsdan ook vanwege het Instituut te begroeten. Met toejuiching vereenigt de Vergadering zich met dit voorstel en worden de hh. Quarles van Ufford en Wijnmalen aangewezen de aangename taak te vervullen.

Door den Penningmeester worden der Vergadering eenige financieele mededeelingen gedaan, waaruit blijkt, dat tegen November a.s. over een som van $f 1000$ ter aflossing der hypotheek kan worden beschikt.

Overeenkomstig zijn voorstel wordt goedgekeurd die som voor dat doel te bestemmen

Met het oog op mogelijk brandgevaar wordt de aankoop wenschelijk geacht van een zoogenaamden veiligheidslantaarn, alsmede van de plaatsing 't zij van een extincteur, 't zij van een ander brandbluschmiddel. Ook wordt in overweging gegeven het aanbrengen eener gasverlichting aan de hoofddeur van het gebouw.

Overeenkomstig het voorstel van den Voorzitter wordt goedgekeurd een en ander aan de aandacht van den Penningmeester en Secretaris aan te bevelen, met verzoek daaromtrent zoo noodig voorstellen te doen.

Niets meer hierna aan de orde zijnde, wordt de Vergadering door den Voorzitter gesloten. 